\title{
Current animal models for the study of congestion in heart failure: an overview
}

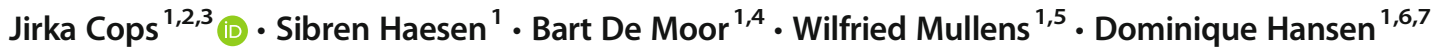

Published online: 5 January 2019

(C) The Author(s) 2019

\begin{abstract}
Congestion (i.e., backward failure) is an important culprit mechanism driving disease progression in heart failure. Nevertheless, congestion remains often underappreciated and clinicians underestimate the importance of congestion on the pathophysiology of decompensation in heart failure. In patients, it is however difficult to study how isolated congestion contributes to organ dysfunction, since heart failure and chronic kidney disease very often coexist in the so-called cardiorenal syndrome. Here, we review the existing relevant and suitable backward heart failure animal models to induce congestion, induced in the left- (i.e., myocardial infarction, rapid ventricular pacing) or right-sided heart (i.e., aorta-caval shunt, mitral valve regurgitation, and monocrotaline), and more specific animal models of congestion, induced by saline infusion or inferior vena cava constriction. Next, we examine critically how representative they are for the clinical situation. After all, a relevant animal model of isolated congestion offers the unique possibility of studying the effects of congestion in heart failure and the cardiorenal syndrome, separately from forward failure (i.e., impaired cardiac output). In this respect, new treatment options can be discovered.
\end{abstract}

Keywords Animal model $\cdot$ Congestion $\cdot$ Inferior vena cava constriction $\cdot$ Central venous pressure

\section{Introduction}

Heart failure is a major public health problem affecting over 23 million people worldwide [1] and is defined as a condition whereby the heart is not able to maintain adequate organ

Jirka Cops and Sibren Haesen are equally contributing authors

Jirka Cops

jirka.cops@uhasselt.be

1 BIOMED - Biomedical Research Institute, Faculty of Medicine and Life Sciences, Hasselt University, Diepenbeek, Belgium

2 Doctoral School for Medicine and Life Sciences, Hasselt University, Diepenbeek, Belgium

3 Hasselt University, BIOMED, Martelarenlaan 42, 3500 Hasselt, Belgium

4 Department of Nephrology, Jessa Ziekenhuis, Hasselt, Belgium

5 Department of Cardiology, Ziekenhuis Oost-Limburg, Genk, Belgium

6 REVAL - Rehabilitation Research Center, Faculty of Rehabilitation Sciences, Hasselt University, Diepenbeek, Belgium

7 Heart Centre Hasselt, Jessa Ziekenhuis, Hasselt, Belgium perfusion in the face of normal filling pressures. It comprises both forward failure (i.e., impaired cardiac output) and backward failure (i.e., venous congestion). Venous congestion, as quantified by the central venous pressure (CVP), is the most important factor driving worsening in renal function in patients with heart failure [2]. Congestion is characterized by an increased CVP and intra-abdominal pressure (IAP) (> $8 \mathrm{mmHg}$ ) [2, 3]. Hemodynamic congestion is defined as a state of increased intra-cardiac filling without clear clinical manifestations [4]. Clinical congestion occurs later and is evidenced by signs and symptoms such as dyspnea, orthopnea, pulmonary rales, edema, and jugular venous distention $[4,5]$. Systemic congestion refers to a general state of congestion characterized by fluid accumulation outside the lungs, accompanied with the aforementioned signs and symptoms [6].

Congestion is classically explained as the consequence of increased cardiac filling pressures, by activation of the neurohumoral and sympathetic nervous system, to compensate a reduced cardiac output (CO). Cardiac filling pressures increase due to ventricular interdependence or due to chronically elevated left-sided filling pressures transmitted back through the pulmonary system into the right ventricle [5], resulting in systemic congestion. The excessive fluid is stored in the splanchnic venous system, which contains highly 
compliant capacitance veins that can store up to $65 \%$ of the total blood volume without repercussions on system hemodynamics [7, 8]. In an attempt to increase the effective circulatory volume, sympathetic stimulation induces vasoconstriction of the splanchnic capacitance vessels and vasodilation of the hepatic veins [9]. The redistribution of this excessive fluid from the capacitance veins to the central venous system, rather than an absolute volume overload, seems to be the most important mechanism contributing to increased cardiac filling pressures [3, 9-11].

The consequences of congestion are not easy to explore in clinical trials, since concomitant forward failure and underlying chronic kidney disease often coexist in patients. Consequently, a wide variety of therapeutics, shown to be beneficial in heart and kidney failure separately, are administered to patients in an attempt to reduce congestion. However, in the clinical setting, the treatment for congestion remains to be optimized. Therefore, further fundamental research in animal models, realistically representing congestion, is necessary. We are the first to review the existing clinically relevant and suitable animal models for the study of congestion, since adequate experimental modeling of the real-life scenario is crucial to examine disease mechanisms and to develop potential therapeutic strategies. In this paper, we will review the existing animal models of heart failure, induced by backward failure, and more specifically congestion.

\section{Animal models of heart failure: backward failure}

Numerous animal models are available to discuss the cardiorenal syndrome, as reviewed by Hewitson et al. [12]. However, these are based on the Ronco classification, which does not focus on the pathophysiological characteristics of the disease [13]. Hemodynamic changes and venous congestion are considered to be the main driving forces contributing to worsening in renal function in heart failure and the cardiorenal syndrome. Heart failure includes both forward failure and backward failure. During backward failure, one or both ventricles fail to eject blood normally thereby causing back pressure on the atria and the venous system and eventually resulting in venous congestion. Eventually, the cardiorenal syndrome develops as renal function is affected by venous congestion [2, 14]. Heart failure associated with congestion is termed congestive heart failure (CHF). Backward failure can be induced in the left- (i.e., myocardial infarction, rapid ventricular pacing) or right-sided heart (i.e., aorta-caval shunt, mitral valve regurgitation, and monocrotaline) in different species by various techniques.

These backward failure models only qualify as a relevant model of venous congestion, if the following conditions are met; (1) CVP has to increase above the upper limit of normal (>8 $\mathrm{mmHg}$ ), since this is the most important characteristic of congestion contributing to a worsening in renal function in patients; (2) edema or a congestive state is required to be present; (3) the experimental method to induce backward failure should not be toxic or affect left ventricular, valvular or pulmonary function, and morphology; and (4) only the rightsided heart and/or venous system should be affected by backward failure (Fig. 1). The following existing animal models of backward failure do not always meet these requirements as explained in the next sections and Table 1.

\section{Myocardial infarction}

Myocardial ischemia and subsequent left ventricular (LV) remodeling is the leading cause of CHF [72]. In rodents, the induction of myocardial infarction (MI), by ligation of the left anterior coronary artery, is a commonly used model of CHF, since congestive features are present due to increased filling pressures (LVEDP $6.1 \pm 2.0$ in MI rats vs. $4.5 \pm 1.2$ in control rats, $p<0.05)[15,16,73]$. In addition, Pfeffer et al. [15] demonstrated that right atrial pressure rises $(4.4 \pm 0.6 \mathrm{mmHg}$
Fig. 1 Characteristics of the ideal animal model for the study of congestion in heart failure

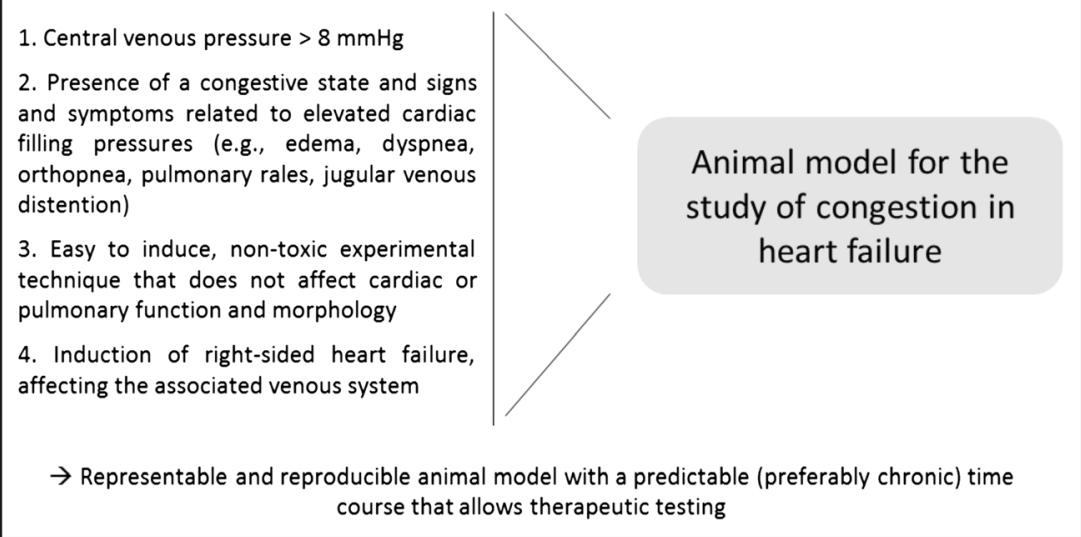




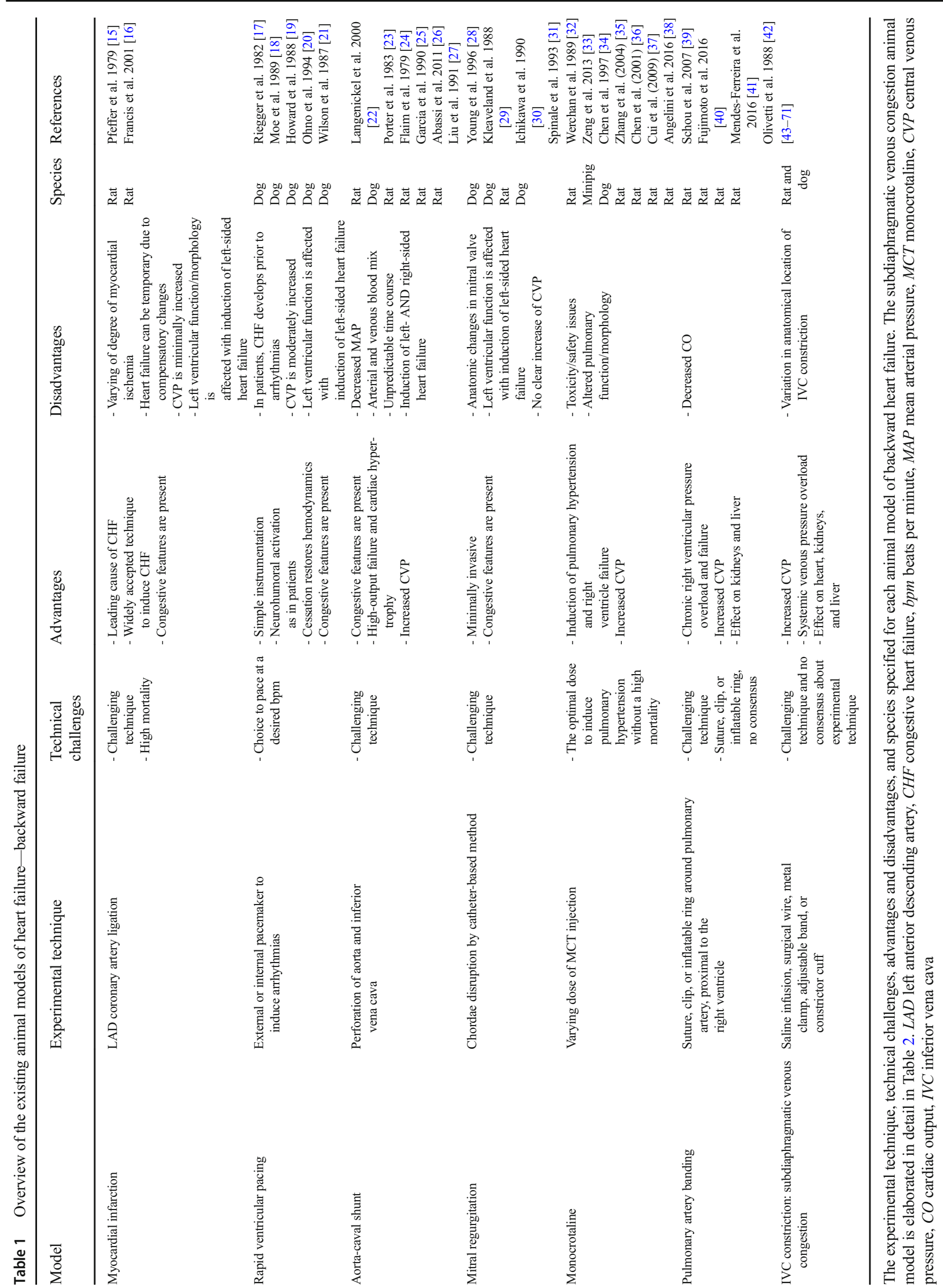


in MI rats vs. $0.4 \pm 0.2$ in control rats) when the infarction covers more than $46 \%$ of total LV endocardial circumference, accompanied by a reduction in systolic $(118 \pm 3 \mathrm{mmHg}$ in MI rats vs. $43 \pm 3 \mathrm{mmHg}$ in control rats, $p<0.01)$ and mean arterial pressure $(105 \pm 3 \mathrm{mmHg}$ vs. $121 \pm 3 \mathrm{mmHg}, p<0.01)$. This eminent sign of hemodynamic congestion is positively correlated with increased blood arginine vasopressin concentrations $\left(R^{2}=0.5949, p<0.05\right)$, contributing to sodium and water retention $(p<0.05)$ [16]. However, acute coronary occlusion often fails to induce stable heart failure because compensatory changes, such as neurohormonal activation, development of a collateral circulation, and left ventricular dilation to maintain stroke volume, do occur and animals rarely develop the atherosclerotic lesions associated with heterogeneous blood flow and inconsistent myocardial lesions, typically seen in humans [74]. In addition, the degree of myocardial ischemia resulting from coronary artery occlusion may vary widely, as shown by Lowe et al. [75] in which occlusion of the same vessel at the same anatomical site in dogs resulted in a significant variation in infarct size $(<10 \%$ to $>70 \%)$. Much of this variation can be explained by differences in the pattern of distribution of the occluded coronary artery [75]. However, due to this large variation, this model is less relevant since repetitions of the animal model should ideally yield the same degree of myocardial ischemia.

\section{Rapid ventricular pacing}

Arrhythmias are often involved in the CHF process as well [76]. Therefore, rapid ventricular pacing-induced tachycardia, often applied in dogs, is used to mimic arrhythmias as seen in patients as it requires simple instrumentation and induces neurohumoral activation closely related to the clinical situation, after 8 weeks of pacing (increase in plasma norepinephrine from $293 \pm 15 \mathrm{pg} / \mathrm{ml}$ at baseline to $1066 \pm 99 \mathrm{pg} / \mathrm{ml}$ after 8 weeks of pacing $(p<0.01)$ vs. $270 \pm 34 \mathrm{~g} / \mathrm{ml}$ in control group; increase in plasma renin activity from $1.4 \pm$ $0.4 \mathrm{ng} / \mathrm{ml} / \mathrm{h}$ at baseline to $10.2 \pm 2.4 \mathrm{ng} / \mathrm{ml} / \mathrm{h}$ after 8 weeks of pacing $(p<0.01)$ vs. $1.7 \pm 0.5 \mathrm{ng} / \mathrm{ml} / \mathrm{h}$ in control group; increase in plasma aldosterone from $124 \pm 42 \mathrm{p} / \mathrm{ml}$ at baseline to $577 \pm 151 \mathrm{pg} / \mathrm{ml}$ after 8 weeks of pacing $(p<0.01)$ vs. 124 $\pm 43 \mathrm{pg} / \mathrm{ml}$ in control group) and the neurohumoral activation returns to baseline levels after resumption of sinus rhythm [17, 18]. After 1-2 months of pacing, the rapid ventricular pacing model is characterized by increased LV filling pressures (LVEDP $34.3 \pm 7.7$ in paced dogs vs. $9.8 \pm 4.6 \mathrm{mmHg}$ in control group, $p<0.05)$ [20], pulmonary wedge pressures $(26 \pm$ $8 \mathrm{mmHg}$ in paced dogs vs. $10 \pm 3 \mathrm{mmHg}$ in control dogs, $p<0.01)$, and right atrial pressures $(13 \pm 3 \mathrm{mmHg}$ in paced dogs vs. $4 \pm 1 \mathrm{mmHg}$ in control dogs, $p<0.01$ ), and is associated with ascites, pulmonary congestion, and low-output failure (CO $116 \pm 14 \mathrm{ml} / \mathrm{min} / \mathrm{kg}$ in paced dogs vs. $130 \pm$ $20 \mathrm{ml} / \mathrm{min} / \mathrm{kg}$ in control group, $p<0.01)$ [20, 21]. Cessation of pacing restores hemodynamic alterations within 4 weeks, which is a unique feature of this CHF model [19]. However, this model fails to demonstrate the true underlying mechanisms of CHF since patients develop CHF first before fatal ventricular arrhythmias occur [77].

\section{Aorta-caval shunt}

Chronic volume overload can be achieved in rats and dogs by the creation of aorta-caval shunt (ACS), also known as an arteriovenous fistula $[22,23]$. The application of a shunt results in a decreased mean arterial pressure $(89 \pm 1 \mathrm{mmHg}$ in ACS rats vs. $108 \pm 2 \mathrm{mmHg}$ in control rats) and increased cardiac weight $(1496 \pm 45 \mathrm{mg}$ in ACS rats vs. $1079 \pm 35 \mathrm{mg}$ in control rats, $p<0.01)$, central venous pressure $(16.4 \pm$ $3.9 \mathrm{mmHg}$ in ACS rats vs. $4.5 \pm 1.6 \mathrm{mmHg}$ in control rats, $p<0.05)$ and left ventricular end-diastolic pressure $(8.6 \pm$ $0.9 \mathrm{mmHg}$ in ACS rats vs. $5.7 \pm 0.7 \mathrm{mmHg}$ in control rats, $p<0.01$ ) [22], thereby leading to ascites, edema, and pleural congestion $[24,26]$. To create a shunt or fistula, the abdominal inferior vena cava (IVC) and aorta are exposed by a laparotomy. The aorta is punctured with an 18-gauge needle and the needle is advanced into the vessel, perforating the adjacent wall between the aorta and vena cava until penetration in the vena cava [25]. Usually, a shunt is created between the aorta and vena cava, the femoral artery and femoral vein, or the carotid artery and internal jugular vein. This experimental model is considered a unique model of high-output heart failure, with a concomitant higher CO $(114.9 \pm 15.5 \mathrm{ml} / \mathrm{min}$ in ACS rats vs. $72.6 \mathrm{ml} / \mathrm{min}$ in control rats, $p<0.05)$, and cardiac hypertrophy [26, 27]. However, the time course for the development of heart failure is less predictable. In addition, arterial blood is able to mix with venous blood, creating artificially increased cardiac filling and central venous pressures, which is not seen in the clinical situation.

\section{Mitral valve regurgitation}

Volume overload can also be induced in a canine model by mitral valve regurgitation by a catheter-based method of chordae disruption [28]. Chronic mitral regurgitation produces left ventricular dilatation and hypertrophy as evidenced by an increased end-diastolic volume $(48 \pm 9 \mathrm{ml}$ at baseline vs. $85 \pm$ $19 \mathrm{ml}$ after 3 months, $p<0.01)$, end-systolic volume $(19 \pm$ $5 \mathrm{ml}$ at baseline vs. $27 \pm 7 \mathrm{ml}$ after 3 months, $p<0.05$ ), enddiastolic pressure $(9 \pm 3 \mathrm{mmHg}$ at baseline vs. $19 \pm 6 \mathrm{mmHg}$ after 3 months, $p<0.01)$, stroke volume $(29 \pm 7 \mathrm{ml}$ at baseline vs. $58 \pm 14 \mathrm{ml}$ after 3 months, $p<0.01$ ), left ventricular mass ( $71 \pm 13 \mathrm{~g}$ at baseline vs. $90 \pm 10 \mathrm{~g}$ after 3 months, $p<0.01)$, and a decreased CO $(2.30 \pm 0.61 \mathrm{l} / \mathrm{min}$ at baseline vs. $1.80 \pm$ $0.64 \mathrm{l} / \mathrm{min}$ after 3 months, $p<0.05$ ) and mean aortic pressure $(100 \pm 11 \mathrm{mmHg}$ at baseline vs. $78 \pm 8 \mathrm{mmHg}$ after 3 months, $p<0.01$ ) [29]. Additionally, mean pulmonary artery pressure 
(13 $\pm 2 \mathrm{mmHg}$, at baseline vs. $19 \pm 5 \mathrm{mmHg}$ after 3 months, $p<0.05$ ) was also significantly increased, and hypothetically, this augmented pulmonary artery pressure may also be transmitted back to the venous system [29]. Indeed, Ichikawa et al. (1989) reported that CVP increases in a canine model of mitral valve regurgitation, although not yet reaching statistical significance $\left(6.0 \pm 1.8 \mathrm{cmH}_{2} \mathrm{O}(=4.4 \pm 1.3 \mathrm{mmHg})\right.$ in mitral regurgitation group compared to $4.6 \pm 1.4 \mathrm{cmH}_{2} \mathrm{O} \quad(=3.4 \pm$ $1.0 \mathrm{mmHg}$ ) in control group) [30]. Notwithstanding, CVP of this particular animal model is not commonly reported in literature. Hence, it is not clear if mitral valve regurgitation has a clear effect on CVP. Myocytes are lengthened $(94 \pm 4 \mu \mathrm{m}$ in mitral regurgitation dogs vs. $218 \pm 8 \mu \mathrm{m}$ in control group, $p<0.05$ ) and demonstrate a reduced contractility [31]. As a result, chronic volume overload is induced, leading to left ventricular dilation and heart failure. This model has the advantage of being minimally invasive despite the fact that anatomic changes in the mitral valve are produced. However, the validity of this animal model is disputable.

\section{Monocrotaline}

Monocrotaline (MCT) injections have been used in rats and minipigs to induce pulmonary hypertension (right ventricular systolic pressure in rats; $77 \pm 13 \mathrm{mmHg}$ in MCT vs. $26 \pm$ $2 \mathrm{mmHg}$ in control group, $p<0.01$ and mean pulmonary artery pressure in minipigs; $24.62 \pm 1.38 \mathrm{mmHg}$ in MCT vs. $15.19 \pm 0.70 \mathrm{mmHg}$ in control group, $p<0.01$ ) and rightsided heart failure $[32,33]$. MCT is a pyrrolizidine alkaloid that causes a pulmonary vascular syndrome characterized by proliferative pulmonary vasculitis, pulmonary hypertension, and cor pulmonale [78]. The mechanism causing pulmonary hypertension remains poorly understood [79]. Nonetheless, MCT is known to increase capillary permeability and to induce interstitial edema, fibrosis, macrophage accumulation, and alveolar edema [78]. Eventually, increased pulmonary vascular resistance leads to pressure overload of the right ventricle, as evidenced by an increased right ventricular weight in both rats $(0.086 \pm 0.007 \mathrm{~g}$ in MCT vs. $0.038 \pm 0.001 \mathrm{~g}$ in control group, $100 \%$ increase) and minipigs (11.05 $\pm 0.5 \mathrm{~g}$ in MCT vs. $8.6 \pm 0.3 \mathrm{~g}$ in control group, $p<0.01)$ subjected to MCT treatment $[32,33]$. Depending on the dose, pulmonary hypertension is developed in a few weeks [79]. Chronic pulmonary hypertension is characterized by a significantly increased mean right ventricular pressure $(13.2 \pm 0.6 \mathrm{mmHg}$ in MCT vs. $9.2 \pm 0.3 \mathrm{mmHg}$ in control group, $p<0.0001)$ [34], mean pulmonary artery pressure $(24.9 \pm 3.7 \mathrm{mmHg}$ in MCT vs. $15.6 \pm 1.6 \mathrm{mmHg}$ in control group, $p<0.0001)$ [33], and CVP $(5.7 \pm 2.8 \mathrm{mmHg}$ in MCT vs. $0.9 \pm 0.3 \mathrm{mmHg}$ in control group, $p<0.01)$ [35]. CVP increased on average by 414 to $767 \%$ after MCT treatment [35-37]. MCT also contributes to kidney injury as demonstrated by significantly increased serum creatinine $(3.06 \pm 1.3 \mathrm{pg} / \mathrm{ml}$ in MCT rats vs. $0.54 \pm$
$0.23 \mathrm{pg} / \mathrm{ml}$ in control group, $p<0.05)$ and serum $(562.7 \pm$ $93.34 \mathrm{ng} / \mathrm{ml}$ in MCT rats vs. $245.3 \pm 58.19 \mathrm{ng} / \mathrm{ml}$ in control group, $p<0.05)$, renal and cardiac tissue $(70,680 \pm 4337$ arbitrary units (AU) in MCT rats vs. 32,120 $44961 \mathrm{AU}$ in control rats, $p<0.01$ ), and neutrophil gelatinase-associated lipocalin (NGAL) levels in rats [38]. However, MCT-related toxicity to the myocardium restricts the relevance of this model to study right ventricular failure [80].

\section{Pulmonary artery banding}

Pulmonary artery banding (PAB) causes chronic pressure overload leading to right-sided heart failure and is performed by placing a suture, clip, or inflatable ring around the pulmonary artery proximally to the right ventricle [80]. Consequently, right ventricular systolic $(114.3 \pm 7.1 \mathrm{mmHg}$ in PAB rats vs. $36.1 \pm 1.7 \mathrm{mmHg}$ in control rats, $p<0.05$ ) and diastolic pressures $(5.4 \pm 1.1 \mathrm{mmHg}$ in PAB rats vs. 3.3 $\pm 1.1 \mathrm{mmHg}$ in control rats, $p<0.05)$ rise [39], $\mathrm{CO}$ is reduced $(78.2 \pm 27.6 \mathrm{ml} / \mathrm{min}$ in PAB rat vs. $150.1 \pm 31.2 \mathrm{ml} / \mathrm{min}$ in control rats, $p<0.01$ ), right ventricular weight increases up to $100-200 \%$, and hepatic function is affected, as evidenced by increased plasma liver enzymes (plasma alkaline phosphatase $160 \pm 7 \mathrm{U} / \mathrm{L}$ in PAB rats vs. $105 \pm 7 \mathrm{U} / 1$ in control rats, $p<0.05)[39,40]$. PAB is an effective method to induce rightsided heart failure, accompanied by signs of backward failure, such as hepatic congestion (43\% of PAB rats), ascites (29\% of PAB rats), and hydrothorax (43\% of PAB rats) [39, 40]. Hepatic fibrosis develops due to tissue hypoxia resulting from a low CO [40]. Mendes-Ferreira et al. [41] showed that a mild PAB constriction resulted in cardiac hypertrophy with a preserved function, while a severe constriction leads to right ventricle dysfunction, remodeling, and fibrosis in just 3 weeks. Impairment of the right ventricular function increases right ventricular systolic pressure $(71 \pm 12 \mathrm{mmHg}$ in PAB rats vs. $33 \pm 11 \mathrm{mmHg}$ in control rats, $p<0.0001)$ and right ventricular end-diastolic pressure $(10 \pm 3 \mathrm{mmHg}$ in PAB rats vs. $3 \pm$ $1 \mathrm{mmHg}$ in control rats, $p<0.0001$ ) which is transmitted back to the venous system, thereby disturbing venous return and increasing central venous pressure $(10 \pm 3 \mathrm{mmHg}$ in PAB rats vs. $2 \pm 0.2 \mathrm{mmHg}$ in control rats, $p<0.0001)$ [40, 42].

In conclusion, the PAB animal model seems to be the most relevant and appropriate animal model of backward failure to induce congestion, since PAB augments the right ventricular pressure and CVP resulting in a congestive state and rightsided heart failure.

\section{Animal models of isolated systemic congestion}

In the previous section, we summarized the available animal models of heart failure induced by backward failure. None of 
the models described above fully qualify as a clinically relevant model of congestion. The most commonly employed surrogate for venous congestion has been central venous pressure (CVP). Current knowledge about CVP contributing to renal dysfunction originates from animal experiments performed in the 1850s. Ludwig (1856) demonstrated that urine output decreases as soon as the CVP is raised above $10 \mathrm{mmHg}$ [81]. Later, hemodynamic experiments performed on isolated canine and rat kidneys confirmed the negative impact of venous congestion on renal function, as a CVP $>19 \mathrm{mmHg}$ was transmitted backwards leading to an increased renal interstitial pressure, sodium retention, and a reduced renal blood flow $[82,83]$. More recently, the ESCAPE trial showed that right atrial pressure is the only hemodynamic parameter associated with renal insufficiency [84], suggesting an important role for (renal) congestion [85]. Based on these arguments, an animal model with an increased CVP seems to be the most appropriate animal model of congestion and should be preferred.

\section{Saline infusion}

Recently, a rat model of acute renal congestion has been described by Komuro et al. [86]. In this model, the femoral vein was cannulated with an indwelling catheter for the simultaneous monitoring of the CVP and injection of saline to create the acute renal congestion model. A bolus of saline is injected until the CVP increased to $10-15 \mathrm{mmHg}$ [86]. However, being an acute model of renal congestion, the chronic phase cannot be investigated and systemic congestion was not induced. Hence, this model is not preferable.

\section{Inferior vena cava constriction: subdiaphragmatic venous congestion}

In the past, efforts have been made to induce isolated venous congestion in animal models by restricting the diameter of the inferior vena cava (IVC) (Table 2). In this way, the CVP increases above the upper limit of normal ( $>8 \mathrm{mmHg}$ ), thereby inducing venous congestion in a similar way as seen in patients [2]. Tying a surgical wire [43-58]; inserting a metal clamp [59, 60], adjustable band [61-64], or constrictor cuff around the IVC $[65,66]$; or placing an inflatable balloon via the femoral vein $[49,53,67-69]$ are frequently used techniques to constrict the IVC. As a result, CVP varied between 11 to $15 \mathrm{mmHg}$ below the constriction while the CVP above the constriction remained unchanged [44, 65].

IVC constriction affects the kidneys, heart, and liver, thereby inducing subdiaphragmatic venous congestion. Regarding the impact of congestion on the kidneys, subdiaphragmatic venous congestion in dogs [44, 52] and rats [59] is associated with decreased urinary sodium excretion and urine volume, but without significant changes in glomerular filtration rate (GFR). Reinhardt et al. [48] demonstrated that constriction of the IVC above the renal veins resulted in a progressive fall of urinary volume from 72 to $0.4 \%$ of total water uptake. In addition, Ishikawa et al. [54] showed that subdiaphragmatic venous congestion reduced water excretion and renal blood flow, without changing GFR. An increased renal venous pressure leads to fluid and sodium redistribution, originally destined for urinary excretion, into the lymphatic system, thereby accounting for the attenuated urine flow and fluid and sodium retention in heart failure [68]. Second, subdiaphragmatic venous congestion may affect the heart by reducing $\mathrm{CO}$ and this being the most likely stimulus for the observed sodium retention [52]. Finally, the liver is a vulnerable target of subdiaphragmatic venous congestion since an increased CVP is transmitted back to the hepatic veins [87], which clinically contributes to the development of fibrosis [58] and eventually to congestive hepatopathy, possibly through the mechanism of sinusoidal thrombosis, according to Simonetto et al. [57].

Most of the existing animal models of subdiaphragmatic congestion do not meet the criteria to be a clinically relevant animal model of isolated congestion (Table 2). First, the exact technique to induce congestion [44, 45, 47, 48, 55, 56], the anatomical location of where the constriction is applied [44, $46,49,52,53,59-68]$, and the degree of constriction were not always properly described $[46,47,50,52,54,56,65,66,68$, 69]. Second, it was not always clear whether venous congestion was actually induced, since hemodynamic or echocardiographic measurements were not performed in these studies [46-52, 54-56, 58, 59, 69]. Third, often a local and no systemic congestion was induced, when the abdominal IVC was constricted at the level of the renal or hepatic veins $[43,47,48$, $50,51,54-58,68]$, in contrast to patients in which the abdomen's entire venous system is congested, potentially explaining contradicting results in animal models versus clinical trials. Fourth, the chronic phase of congestion - weeks to months - was not investigated as the constriction was only maintained for hours to days, or the animals were only often studied for a few days [44-56, 58-69]. Finally, the effect of constriction on abdominal organ function, besides the kidneys, was not investigated $[47,51,54,58,61-64,67-69]$. Taken together, the lack of sufficient information regarding the application of acute or chronic constriction, using a wide variety of techniques on different anatomical positions, makes it difficult to compare results.

\section{Development of a new rat model of abdominal venous congestion}

Recently, the authors developed a new rat model of abdominal venous congestion by addressing these aforementioned limitations [70]. They opted to constrict the IVC in the thoracic cavity in an easy-accessible rat model. In this way, all 


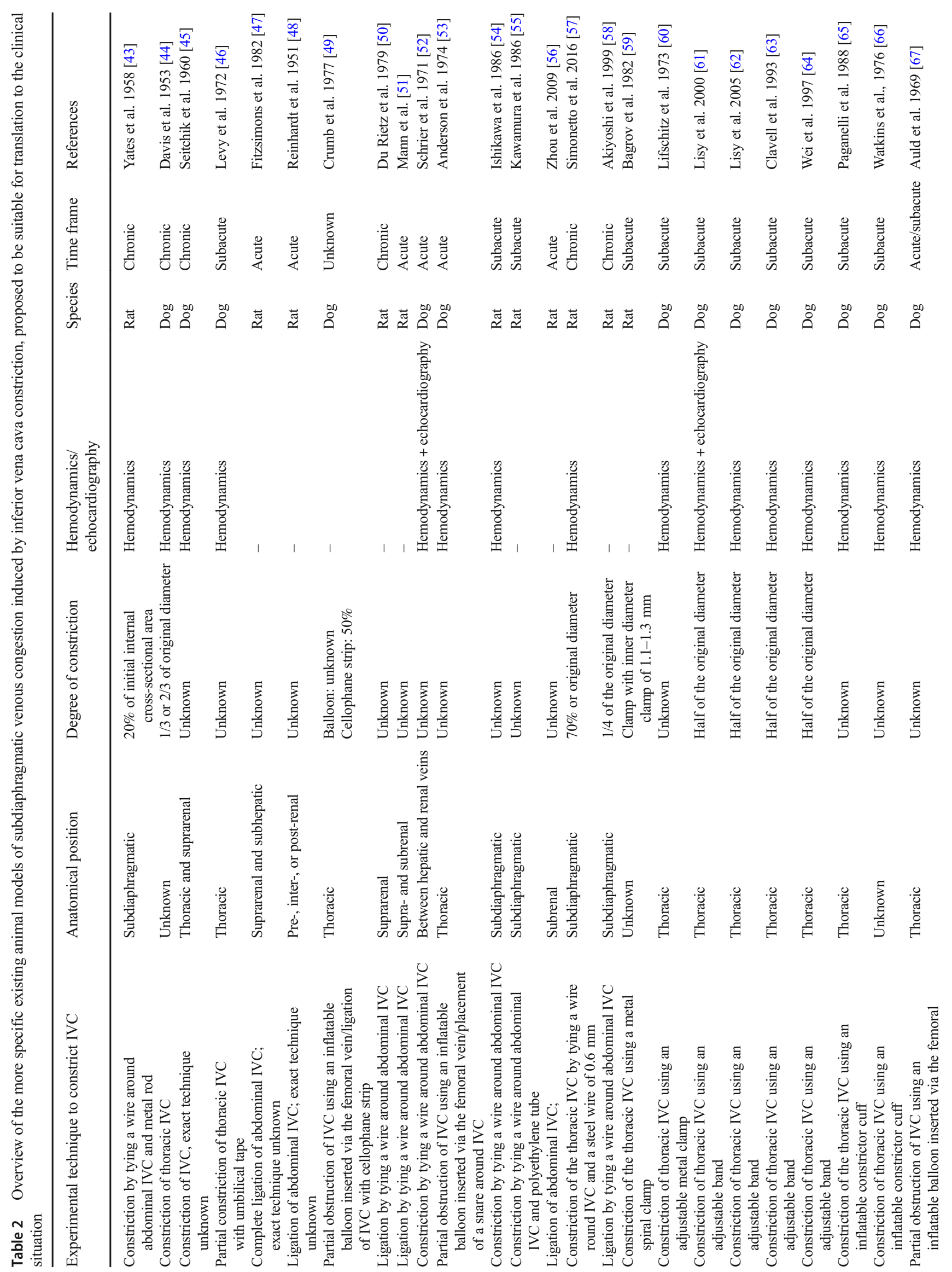


abdominal organs are affected by the increased CVP and abdominal venous congestion is developed consequently. Briefly, a permanent constriction above the diaphragm was applied by tying a surgical wire around the IVC and a 20 gauge $(0.812 \mathrm{~mm})$ needle, after which the needle was immediately removed. The chronic effects of abdominal venous congestion were investigated in this model for a period of 12 weeks. The main findings of this study are that (1) the average abdominal venous pressure of the IVCc group was significantly increased compared to the SHAM group (mean $13.8 \mathrm{mmHg}$ in IVCc rats vs. $4.9 \mathrm{mmHg}$ in SHAM rats, $p<0.01$ ); (2) kidney function worsened and renal morphometry was altered in IVCc rats, as indicated by a significantly increased plasma creatinine (median $0.33 \mathrm{mg} / \mathrm{dl}$ in IVCc rats vs. $0.28 \mathrm{mg} / \mathrm{dl}$ in SHAM rats, $p<0.05$ ), plasma cystatin C (median $2.11 \mathrm{mg} / \mathrm{dl}$ in IVCc rats vs. $1.25 \mathrm{mg} / \mathrm{dl}$ in SHAM rats, $p<0.01$ ), urinary albumin (median $86.4 \mathrm{mg} / \mathrm{g}$ creatinine in IVCc rats vs. $24.8 \mathrm{mg} / \mathrm{g}$ creatinine in SHAM rats, $p<0.05$ ), glomerular surface area and with of Bowman's space $(p<0.05)$; and (3) cardiac function did not differ between both groups, as a result of abdominal venous congestion induced by thoracic IVC constriction. To summarize, Cops et al. [70] were able to develop a rat model to selectively increase the abdominal venous pressure without compromising cardiac function. These findings exclude the effects of a reduced $\mathrm{CO}$ on organ functioning in this rat model. In a next study, this rat model was investigated for a maximal follow-up of 21 weeks and it was demonstrated that selective abdominal venous congestion induces retrogradely conducted glomerular hypertension, without a concomitant change in GFR, and hepatic morphological and functional alterations, despite a preserved cardiac function [71].

In conclusion, this rat model offers the unique possibility of studying abdominal venous congestion in heart failure and by extension in the cardiorenal syndrome [70,71]. This is important since it remains unclear in which manner venous congestion contributes to cardiac and renal dysfunction in patients, and to develop effective therapeutic strategies in the future.

\section{General conclusion}

Congestion, as part of backward failure in heart failure, is an important player in the pathophysiology of heart failure and the cardiorenal syndrome. Nonetheless, the exact disease mechanisms remain to be elucidated and further fundamental research is necessary. In the past, different techniques have been described to induce backward failure in animal models. Unfortunately, these models are not truly a model of congestion, as explained before. Since an increased CVP is such a strong determinant of congestion, a whole spectrum of techniques has been described to constrict the IVC in an attempt to increase the CVP, above the upper limit of normal, and in this 
way qualifying as model of congestion. To date, the rat model in which selective abdominal venous congestion was induced by a permanent surgical constriction with a 20 -gauge needle seems to be a clinically relevant animal model of congestion, since the drawbacks of the previous subdiaphragmatic venous congestion models are corrected in the current model.

Funding This work was funded by Bijzonder Onderzoeksfonds (BOF) from UHasselt/BIOMED to JC.

\section{Compliance with ethical standards}

Conflict of interest The authors declare that that they have no conflict of interest.

Ethical approval Since this is a review article, this article does not contain any studies with human participants or animals performed by any of the authors.

Open Access This article is distributed under the terms of the Creative Commons Attribution 4.0 International License (http:// creativecommons.org/licenses/by/4.0/), which permits unrestricted use, distribution, and reproduction in any medium, provided you give appropriate credit to the original author(s) and the source, provide a link to the Creative Commons license, and indicate if changes were made.

Publisher's Note Springer Nature remains neutral with regard to jurisdictional claims in published maps and institutional affiliations.

\section{References}

1. Bui AL, Horwich TB, Fonarow GC (2011) Epidemiology and risk profile of heart failure. Nat Rev Cardiol 8(1):30-41. https://doi.org/ 10.1038/nrcardio.2010.165

2. Mullens W, Abrahams Z, Francis GS, Sokos G, Taylor DO, Starling RC, Young JB, Tang WH (2009) Importance of venous congestion for worsening of renal function in advanced decompensated heart failure. J Am Coll Cardiol 53(7):589-596. https://doi.org/10.1016/j. jacc.2008.05.068

3. Mullens W, Abrahams Z, Skouri HN, Francis GS, Taylor DO, Starling RC, Paganini E, Tang WH (2008) Elevated intraabdominal pressure in acute decompensated heart failure: a potential contributor to worsening renal function? J Am Coll Cardiol 51(3):300-306. https://doi.org/10.1016/j.jacc.2007.09.043

4. Gheorghiade M, Filippatos G, De Luca L, Burnett J (2006) Congestion in acute heart failure syndromes: an essential target of evaluation and treatment. Am J Med 119(12 Suppl 1):S3-s10. https://doi.org/10.1016/j.amjmed.2006.09.011

5. Parrinello G, Greene SJ, Torres D, Alderman M, Bonventre JV, Di Pasquale P, Gargani L, Nohria A, Fonarow GC, Vaduganathan M, Butler J, Paterna S, Stevenson LW, Gheorghiade M (2015) Water and sodium in heart failure: a spotlight on congestion. Heart Fail Rev 20(1):13-24. https://doi.org/10.1007/s10741-014-9438-7

6. Dupont M, Mullens W, Tang WH (2011) Impact of systemic venous congestion in heart failure. Curr Heart Fail Rep 8(4):233-241. https://doi.org/10.1007/s11897-011-0071-7

7. Harjola VP, Mullens W, Banaszewski M, Bauersachs J, Brunner-La Rocca HP, Chioncel O, Collins SP, Doehner W, Filippatos GS, Flammer AJ, Fuhrmann V, Lainscak M, Lassus J, Legrand M, Masip J, Mueller C, Papp Z, Parissis J, Platz E, Rudiger A,
Ruschitzka F, Schafer A, Seferovic PM, Skouri H, Yilmaz MB, Mebazaa A (2017) Organ dysfunction, injury and failure in acute heart failure: from pathophysiology to diagnosis and management. A review on behalf of the Acute Heart Failure Committee of the Heart Failure Association (HFA) of the European Society of Cardiology (ESC). Eur J Heart Fail 19(7):821-836. https://doi. org/10.1002/ejhf.872

8. Rubio Gracia J, Sanchez Marteles M, Perez Calvo JI (2017) Involvement of systemic venous congestion in heart failure. Rev Clin Espanola 217(3):161-169. https://doi.org/10.1016/j.rce.2016. 10.012

9. Verbrugge FH, Dupont M, Steels P, Grieten L, Malbrain M, Tang WH, Mullens W (2013) Abdominal contributions to cardiorenal dysfunction in congestive heart failure. J Am Coll Cardiol 62(6): 485-495. https://doi.org/10.1016/j.jacc.2013.04.070

10. Fallick C, Sobotka PA, Dunlap ME (2011) Sympathetically mediated changes in capacitance: redistribution of the venous reservoir as a cause of decompensation. Circ Heart Fail 4(5):669-675. https:// doi.org/10.1161/circheartfailure.111.961789

11. Verbrugge FH, Grieten L, Mullens W (2014) New insights into combinational drug therapy to manage congestion in heart failure. Curr Heart Fail Rep 11(1):1-9. https://doi.org/10.1007/s11897013-0174-4

12. Hewitson TD, Holt SG, Smith ER (2015) Animal models to study links between cardiovascular disease and renal failure and their relevance to human pathology. Front Immunol 6:465. https://doi. org/10.3389/fimmu.2015.00465

13. Ronco C, Haapio M, House AA, Anavekar N, Bellomo R (2008) Cardiorenal syndrome. J Am Coll Cardiol 52(19):1527-1539. https://doi.org/10.1016/j.jacc.2008.07.051

14. Damman K, van Deursen VM, Navis G, Voors AA, van Veldhuisen DJ, Hillege HL (2009) Increased central venous pressure is associated with impaired renal function and mortality in a broad spectrum of patients with cardiovascular disease. J Am Coll Cardiol 53(7): 582-588. https://doi.org/10.1016/j.jacc.2008.08.080

15. Pfeffer MA, Pfeffer JM, Fishbein MC, Fletcher PJ, Spadaro J, Kloner RA, Braunwald E (1979) Myocardial infarct size and ventricular function in rats. Circ Res 44(4):503-512

16. Francis J, Weiss R, Wei S, Johnson A, Felder R (2001) Progression of heart failure after myocardial infarction in the rat. Am J Phys Regul Integr Comp Phys 281(5):R1734-R1745

17. Riegger A, Liebau G (1982) The renin-angiotensin-aldosterone system, antidiuretic hormone and sympathetic nerve activity in an experimental model of congestive heart failure in the dog. Clin Sci 62(5):465-469

18. Moe GW, Stopps TP, Angus C, Forster C, Adolfo J, Armstrong PW (1989) Alterations in serum sodium in relation to atrial natriuretic factor and other neuroendocrine variables in experimental pacinginduced heart failure. J Am Coll Cardiol 13(1):173-179

19. Howard RJ, Stopps TP, Moe GW, Gotlieb A, Armstrong PW (1988) Recovery from heart failure: structural and functional analysis in a canine model. Can J Physiol Pharmacol 66(12):1505-1512

20. Ohno M, Cheng C-P, Little WC (1994) Mechanism of altered patterns of left ventricular filling during the development of congestive heart failure. Circulation 89(5):2241-2250

21. Wilson JR, Douglas P, Hickey WF, Lanoce V, Ferraro N, Muhammad A, Reichek N (1987) Experimental congestive heart failure produced by rapid ventricular pacing in the dog: cardiac effects. Circulation 75(4):857-867

22. Langenickel T, Pagel I, Hohnel K, Dietz R, Willenbrock R (2000) Differential regulation of cardiac ANP and BNP mRNA in different stages of experimental heart failure. Am J Phys Heart Circ Phys 278(5):H1500-H1506. https://doi.org/10.1152/ajpheart.2000.278. 5.H1500 
23. Porter CB, Walsh RA, Badke FR, O'Rourke RA (1983) Differential effects of diltiazem and nitroprusside on left ventricular function in experimental chronic volume overload. Circulation 68(3):685-692

24. Flaim SF, Minteer WJ, Nellis SH, Clark DP (1979) Chronic arteriovenous shunt: evaluation of a model for heart failure in rat. Am J Phys 236(5):H698-H704. https://doi.org/10.1152/ajpheart.1979. 236.5.H698

25. Garcia R, Diebold S (1990) Simple, rapid, and effective method of producing aortocaval shunts in the rat. Cardiovasc Res 24(5):430 432

26. Abassi Z, Goltsman I, Karram T, Winaver J, Hoffman A (2011) Aortocaval fistula in rat: a unique model of volume-overload congestive heart failure and cardiac hypertrophy. J Biomed Biotechnol 2011:729497-729413. https://doi.org/10.1155/2011/729497

27. Liu Z, Hilbelink DR, Crockett WB, Gerdes AM (1991) Regional changes in hemodynamics and cardiac myocyte size in rats with aortocaval fistulas. 1. Developing and established hypertrophy. Circ Res 69(1):52-58

28. Young AA, Orr R, Smaill BH, Dell'Italia LJ (1996) Threedimensional changes in left and right ventricular geometry in chronic mitral regurgitation. Am J Phys 271(6 Pt 2):H2689H2700. https://doi.org/10.1152/ajpheart.1996.271.6.H2689

29. Kleaveland JP, Kussmaul WG, Vinciguerra T, Diters R, Carabello BA (1988) Volume overload hypertrophy in a closed-chest model of mitral regurgitation. Am J Phys 254(6 Pt 2):H1034-H1041. https://doi.org/10.1152/ajpheart.1988.254.6.H1034

30. Ichikawa S, Wakao Y, Muto M, Takahashi M (1990) Experimental studies of the load reducing effects of nitroglycerin in heart failure. Nihon Juigaku Zasshi Jpn J Vet Sci 52(2):361-369

31. Spinale FG, Ishihra K, Zile M, DeFryte G, Crawford FA, Carabello BA (1993) Structural basis for changes in left ventricular function and geometry because of chronic mitral regurgitation and after correction of volume overload. J Thorac Cardiovasc Surg 106(6): 1147-1157

32. Werchan PM, Summer WR, Gerdes AM, McDonough KH (1989) Right ventricular performance after monocrotaline-induced pulmonary hypertension. Am J Phys 256(5 Pt 2):H1328-H1336. https:// doi.org/10.1152/ajpheart.1989.256.5.H1328

33. Zeng GQ, Liu R, Liao HX, Zhang XF, Qian YX, Liu BH, Wu QH, Zhao J, Gu WW, Li HT (2013) Single intraperitoneal injection of monocrotaline as a novel large animal model of chronic pulmonary hypertension in Tibet minipigs. PLoS One 8(11):e78965. https:// doi.org/10.1371/journal.pone.0078965

34. Chen EP, Bittner HB, Craig DM, Davis RD Jr, Van Trigt P III (1997) Pulmonary hemodynamics and blood flow characteristics in chronic pulmonary hypertension. Ann Thorac Surg 63(3):806813

35. Zhang TT, Cui B, Dai DZ (2004) Downregulation of Kv4.2 and Kv4.3 channel gene expression in right ventricular hypertrophy induced by monocrotaline in rat. Acta Pharmacol Sin 25(2):226230

36. Chen L, Gan XT, Haist JV, Feng Q, Lu X, Chakrabarti S, Karmazyn M (2001) Attenuation of compensatory right ventricular hypertrophy and heart failure following monocrotaline-induced pulmonary vascular injury by the $\mathrm{Na}+\mathrm{H}+$ exchange inhibitor cariporide. J Pharmacol Exp Ther 298(2):469-476

37. Cui B, Cheng YS, Dai DZ, Li N, Zhang TT, Dai Y (2009) CPU0213, a non-selective ETA/ETB receptor antagonist, improves pulmonary arteriolar remodeling of monocrotaline-induced pulmonary hypertension in rats. Clin Exp Pharmacol Physiol 36(2):169175. https://doi.org/10.1111/j.1440-1681.2008.05044.x

38. Angelini A, Castellani C, Virzi GM, Fedrigo M, Thiene G, Valente M, Ronco C, Vescovo G (2015) The role of congestion in cardiorenal syndrome type 2: new pathophysiological insights into an experimental model of heart failure. Cardiorenal Med 6(1):6172. https://doi.org/10.1159/000440775
39. Schou UK, Peters CD, Wan Kim S, Frøkiær J, Nielsen S (2007) Characterization of a rat model of right-sided heart failure induced by pulmonary trunk banding. J Exp Anim Sci 43(4):237-254. https://doi.org/10.1016/j.jeas.2006.10.004

40. Fujimoto Y, Urashima T, Shimura D, Ito R, Kawachi S, Kajimura I, Akaike T, Kusakari Y, Fujiwara M, Ogawa K, Goda N, Ida H, Minamisawa S (2016) Low cardiac output leads hepatic fibrosis in right heart failure model rats. PLoS One 11(2):e0148666. https://doi.org/10.1371/journal.pone.0148666

41. Mendes-Ferreira P, Santos-Ribeiro D, Adao R, Maia-Rocha C, Mendes-Ferreira M, Sousa-Mendes C, Leite-Moreira AF, BrasSilva C (2016) Distinct right ventricle remodeling in response to pressure overload in the rat. Am J Phys Heart Circ Phys 311(1): H85-H95. https://doi.org/10.1152/ajpheart.00089.2016

42. Olivetti G, Ricci R, Lagrasta C, Maniga E, Sonnenblick EH, Anversa P (1988) Cellular basis of wall remodeling in long-term pressure overload-induced right ventricular hypertrophy in rats. Circ Res 63(3):648-657

43. Yates FE (1958) Effects of central venous congestion on sodium, potassium and water metabolism in the rat; response to desoxycorticosterone. Am J Phys 194(1):57-64

44. Davis JO, Howell DS (1953) Mechanisms of fluid and electrolyte retention in experimental preparations in dogs: II. With thoracic inferior vena cava constriction. Circ Res 1(2):171-178

45. Seitchik MW, Poll M, Rosenthal W, Baronofsky ID (1961) Studies in the hemodynamics following supradiaphragmatic constriction of the inferior vena cava. Ann Surg 153:71-80

46. Levy M (1972) Effects of acute volume expansion and altered hemodynamics on renal tubular function in chronic caval dogs. J Clin Invest 51(4):922-938. https://doi.org/10.1172/jci106887

47. Fitzsimons JT, Elfont RM (1982) Angiotensin does contribute to drinking induced by caval ligation in rat. Am J Phys 243(5):R558 R562

48. Reinhardt WO (1951) Antidiuretic effect of non-renal venous congestion on renal water excretion by the hydrated rat. Proc Soc Exp Biol Med Soc Exp Biol Med (New York, NY) 77(4):809-812

49. Crumb CK, Minuth AN, Flasterstein AH, Hebert CS, Eknoyan G, Martinez-Maldonado M, Suki WN (1977) Sodium excretion and intrarenal hemodynamics in thoracic inferior vena cava constriction. Am J Phys 232(6):F507-F512

50. Du Rietz B, Ekman R, Olsson AM (1979) Vascular lesions in the rat after ligation of the inferior vena cava above the renal veins. Urol Res 7(4):253-260

51. Mann J, Johnson A, Rascher W, Genest J, Ganten D (1981) Thirst in the rat after ligation of the inferior vena cava: role of angiotensin II. Pharmacol Biochem Behav 15(3):337-341

52. Schrier RW, Humphreys MH, Ufferman RC (1971) Role of cardiac output and the autonomic nervous system in the antinatriuretic response to acute constriction of the thoracic superior vena cava. Circ Res 29(5):490-498

53. Anderson RJ, Cadnapaphornchai P, Harbottle JA, McDonald KM, Schrier RW (1974) Mechanism of effect of thoracic inferior vena cava constriction on renal water excretion. J Clin Invest 54(6): 1473-1479. https://doi.org/10.1172/jci107895

54. Ishikawa S-E, Saito T, Okada K, Tsutsui K, Kuzuya T (1986) Effect of vasopressin antagonist on water excretion in inferior vena cava constriction. Kidney Int 30(1):49-55

55. Kawamura J, Itoh M, Yoshida O (1979) Effect of renal vein ligation with or without suprarenal inferior vena cava ligation on sodium and phosphate excretions during acute extracellular volume expansion in the rat. Investig Urol 16(6):463-467

56. Zhou J, May L, Liao P, Gross PL, Weitz JI (2009) Inferior vena cava ligation rapidly induces tissue factor expression and venous thrombosis in rats. Arterioscler Thromb Vasc Biol 29(6):863-869. https:// doi.org/10.1161/atvbaha.109.185678 
57. Simonetto DA, Yang HY, Yin M, de Assuncao TM, Kwon JH, Hilscher M, Pan S, Yang L, Bi Y, Beyder A, Cao S, Simari RD, Ehman R, Kamath PS, Shah VH (2015) Chronic passive venous congestion drives hepatic fibrogenesis via sinusoidal thrombosis and mechanical forces. Hepatology (Baltimore, Md) 61(2):648659. https://doi.org/10.1002/hep.27387

58. Akiyoshi H, Terada T (1999) Centrilobular and perisinusoidal fibrosis in experimental congestive liver in the rat. J Hepatol 30(3): 433-439

59. Bagrov Y, Gusev G, Krestinskaya T, Manninen V, Mälkönen M, Vasileva V (1982) Kidney and liver function in rats during the edema following constriction of thoracic inferior vena cava with and without adrenalectomy or hypophysectomy. J Intern Med 212(S668): 143-149

60. Lifschitz MD, Schrier RW (1973) Alterations in cardiac output with chronic constriction of thoracic inferior vena cava. Am J Phys 225(6):1364-1370. https://doi.org/10.1152/ajplegacy.1973.225.6. 1364

61. Lisy O, Redfield MM, Jovanovic S, Jougasaki M, Jovanovic A, Leskinen H, Terzic A, Burnett JC Jr (2000) Mechanical unloading versus neurohumoral stimulation on myocardial structure and endocrine function in vivo. Circulation 102(3):338-343

62. Lisy O, Redfield MM, Schirger JA, Burnett JC Jr (2005) Atrial BNP endocrine function during chronic unloading of the normal canine heart. Am J Physiol Regul Integr Comp Physiol 288(1): R158-R162. https://doi.org/10.1152/ajpregu.00444.2004

63. Clavell AL, Stingo AJ, Aarhus LL, Burnett JC Jr (1993) Biological actions of brain natriuretic peptide in thoracic inferior vena caval constriction. Am J Phys 265(6 Pt 2):R1416-R1422. https://doi.org/ 10.1152/ajpregu.1993.265.6.R1416

64. Wei CM, Clavell AL, Burnett JC (1997) Atrial and pulmonary endothelin mRNA is increased in a canine model of chronic low cardiac output. Am J Phys 273(2 Pt 2):R838-R844. https://doi.org/ 10.1152/ajpregu.1997.273.2.R838

65. Paganelli WC, Cant JR, Pintal RR, Kifor I, Barger AC, Dzau VJ (1988) Plasma atrial natriuretic factor during chronic thoracic inferior vena caval constriction. Circ Res 62(2):279-285

66. Watkins L Jr, Burton JA, Haber E, Cant JR, Smith FW, Barger AC (1976) The renin-angiotensin-aldosterone system in congestive failure in conscious dogs. J Clin Invest 57(6):1606-1617. https://doi. org/10.1172/jci108431

67. Auld RB, Alexander EA, Levinsky NG (1971) Proximal tubular function in dogs with thoracic caval constriction. J Clin Invest 50(10):2150-2158. https://doi.org/10.1172/jci106709

68. Katz YJ, Cockett A, MOOR RS (1959) Elevation of inferior vena cava pressure and thoracic lymph and urine flow. Circ Res 7(1): $118-122$

69. Cirksena WJ, Dirks JH, Berliner RW (1966) Effect of thoracic cava obstruction on response of proximal tubule sodium reabsorption to saline infusion. J Clin Invest 45(2):179-186. https://doi.org/10. 1172/jci 105330

70. Cops J, Mullens W, Verbrugge FH, Swennen Q, Reynders C, Penders J, Rigo JM, Hansen D (2018) Selective abdominal venous congestion to investigate cardiorenal interactions in a rat model. PLoS One 13(5):e0197687. https://doi.org/10.1371/journal.pone. 0197687

71. Cops J, Mullens W, Verbrugge FH, Swennen Q, De Moor B, Reynders C, Penders J, Achten R, Driessen A, Dendooven A, Rigo J-M, Hansen D (2018) Selective abdominal venous congestion induces adverse renal and hepatic morphological and functional alterations despite a preserved cardiac function. Sci Rep 8(1):17757. https://doi.org/10.1038/s41598-018-36189-3

72. Pfeffer MA, Braunwald E (1990) Ventricular remodeling after myocardial infarction. Experimental observations and clinical implications. Circulation 81(4):1161-1172

73. Chen Y-F, Weltman NY, Li X, Youmans S, Krause D, Gerdes AM (2013) Improvement of left ventricular remodeling after myocardial infarction with eight weeks L-thyroxine treatment in rats. J Transl Med 11(1):40. https://doi.org/10.1186/1479-5876-11-40

74. Smith HJ, Nuttall A (1985) Experimental models of heart failure. Cardiovasc Res 19(4):181-186

75. Lowe JE, Reimer KA, Jennings R (1978) Experimental infarct size as a function of the amount of myocardium at risk. Am J Pathol 90(2):363

76. Bardy GH, Lee KL, Mark DB, Poole JE, Packer DL, Boineau R, Domanski M, Troutman C, Anderson J, Johnson G (2005) Amiodarone or an implantable cardioverter-defibrillator for congestive heart failure. N Engl J Med 352(3):225-237

77. Yarbrough WM, Spinale FG (2003) Large animal models of congestive heart failure: a critical step in translating basic observations into clinical applications. J Nucl Cardiol 10(1):77-86

78. Wilson DW, Segall HJ, Pan LC, Lame MW, Estep JE, Morin D (1992) Mechanisms and pathology of monocrotaline pulmonary toxicity. Crit Rev Toxicol 22(5-6):307-325. https://doi.org/10. 3109/10408449209146311

79. Nogueira-Ferreira R, Vitorino R, Ferreira R, Henriques-Coelho T (2015) Exploring the monocrotaline animal model for the study of pulmonary arterial hypertension: a network approach. Pulm Pharmacol Ther 35:8-16. https://doi.org/10.1016/j.pupt.2015.09. 007

80. Guihaire J, Bogaard HJ, Flecher E, Noly PE, Mercier O, Haddad F, Fadel E (2013) Experimental models of right heart failure: a window for translational research in pulmonary hypertension. Semin Respir Crit Care Med 34(5):689-699. https://doi.org/10.1055/s0033-1355444

81. Ludwig C (1856) Lehrbuch der Physiologie des Menschen, vol 2. Winter,

82. Firth J, Raine A, Ledingham J (1988) Raised venous pressure: a direct cause of renal sodium retention in oedema? Lancet 331(8593):1033-1036

83. Winton F (1931) The influence of venous pressure on the isolated mammalian kidney. J Physiol 72(1):49-61

84. Nohria A, Hasselblad V, Stebbins A, Pauly DF, Fonarow GC, Shah M, Yancy CW, Califf RM, Stevenson LW, Hill JA (2008) Cardiorenal interactions: insights from the ESCAPE trial. J Am Coll Cardiol 51(13):1268-1274. https://doi.org/10.1016/j.jacc. 2007.08.072

85. Szymanski MK, de Boer RA, Navis GJ, van Gilst WH, Hillege HL (2012) Animal models of cardiorenal syndrome: a review. Heart Fail Rev 17(3):411-420. https://doi.org/10.1007/s10741-0119279-6

86. Komuro K, Seo Y, Yamamoto M, Sai S, Ishizu T, Shimazu K, Takahashi Y, Imagawa S, Anzai T, Yonezawa K, Aonuma K (2018) Assessment of renal perfusion impairment in a rat model of acute renal congestion using contrast-enhanced ultrasonography. Heart Vessel 33(4):434-440. https://doi.org/10.1007/s00380-0171063-7

87. Giallourakis CC, Rosenberg PM, Friedman LS (2002) The liver in heart failure. Clin Liver Dis 6(4):947-967 